
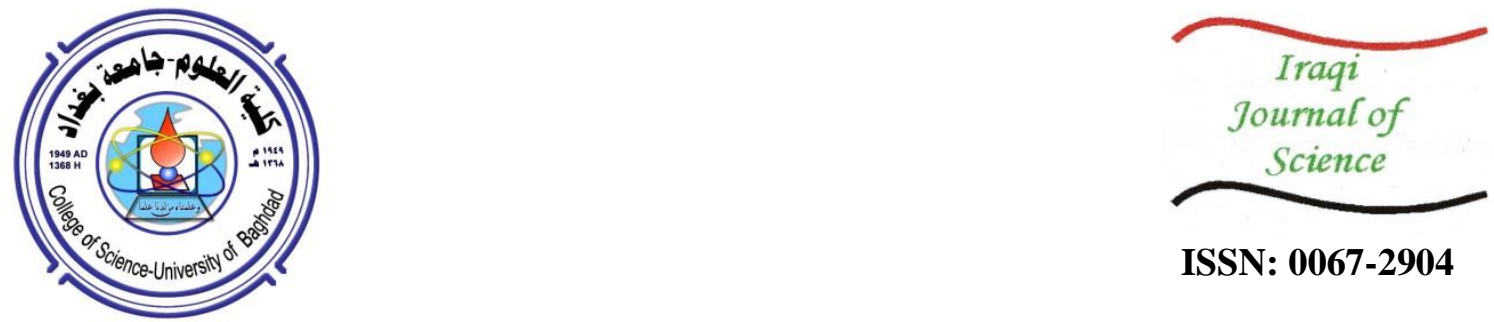

ISSN: 0067-2904

\title{
An Application of Response Surface Methodology for Optimizing the Production of Chitin Deacetylase Enzyme by Aspergillus Flavus
}

\author{
Reem W. Yonis*, Khalid Jaber Kadhum Luti, Ghazi M Aziz \\ Department of Biotechnology, College of Science, University of Baghdad, Baghdad, Iraq
}

\begin{abstract}
In this study, the optimum conditions for chitin deacetylase (CDA) production by Aspergillus flavus $\mathrm{F} 1$ in solid-state fermentation were investigated via two optimization strategies: classical optimization based on the method of one factor at a time and statistical optimization using response surface methodology. The result of classical optimization showed that corn supplemented with $2 \%$ chitin moisturized with mineral salts solution at $\mathrm{pH}=7$ and five days of incubation time were the optimum conditions for increasing CDA production with approximately yield of $219.5 \mathrm{U} / \mathrm{g}$ solid substrate. Furthermore, $\mathrm{pH}$, moisture level and inoculum size were systemically evaluated to improve CDA production based on a central composite design using the Design expert 7 software. Based on the enhanced regression model, a maximum predicted CDA enzyme production of $283.8 \mathrm{U} / \mathrm{g}$ could be obtained with $\mathrm{pH} 8$, moisture level 1:1 (w/v) and inoculum size $3 \mathrm{ml} / 10 \mathrm{~g}$ solid substrate, which contain $1 \times 10^{6}$ spore $/ \mathrm{ml}$. The verification of optimization results and determine accuracy of model showed that the actual response of CDA was $312 \mathrm{U} / \mathrm{g}$, which approximately closed to predicted value $283.89 \mathrm{U} / \mathrm{g}$. The crude extract of CDA was concentrated by sucrose. The results showed that $61 \%$ of CDA enzyme was yielded with a purification fold of 1.1 In addition. Then CDA was purified partially by gel filtration chromatography after concentration by sucrose with total enzyme activity and specific activity of $1476 \mathrm{U}$ and 12300 (U/mg protein) respectively. Furthermore, the produced CDA enzyme showed maximum activity in $\mathrm{pH}$ ranged from (6-8); in which enzyme activity was $69 \mathrm{U} / \mathrm{ml}$. however; the enzyme stability has a wide range in acidic and alkaline $\mathrm{pH}$. In addition, the enzyme was maintained its activity at temperatures from 30 to $55 \mathrm{C}^{\circ}$. Whereas, the activity was declined in temperature up to $55 \mathrm{C}^{\circ}$ with a minimum activity $(8 \mathrm{U} / \mathrm{ml})$ observed at $80 \mathrm{C}^{\circ}$.
\end{abstract}

Keywords: CDA enzyme, Aspergillus flavus, Optimization, RSM, SSF.

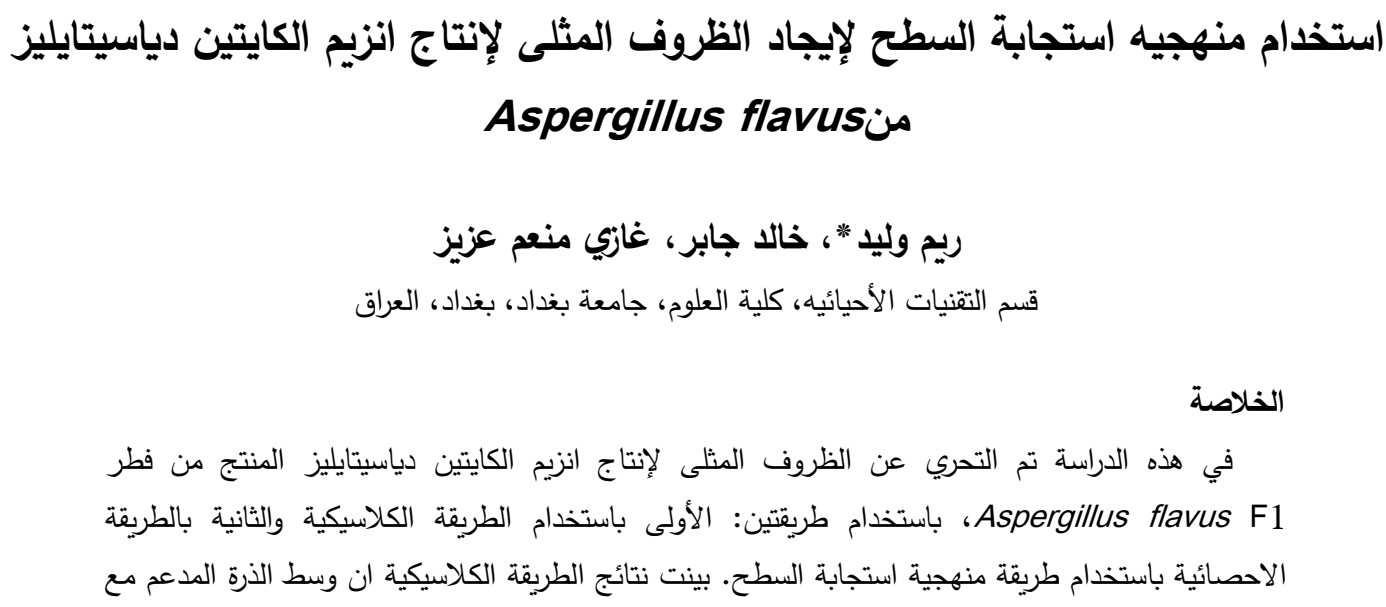

*Email: reemw812003@yahoo.com 


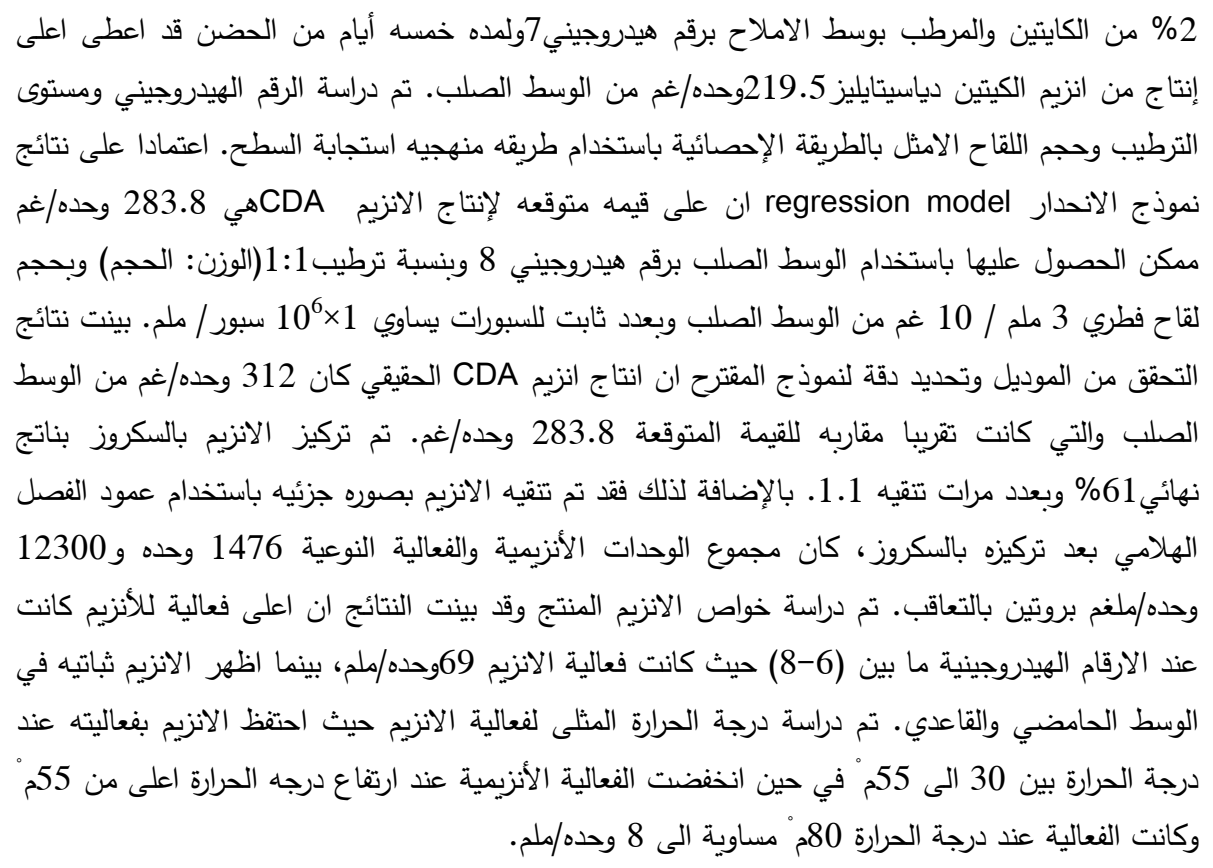

\section{Introduction}

Chitin deacetylase (CDA) enzyme catalyzes the conversion of chitin into chitosan with the deacetylation of N-acetyl-D-glucosamine residues, it was originally identified, partially purified and extracted from the culture of the fungus Mucor rouxii, [1]. This enzyme is an acidic glycoprotein with molecular weight of approximately $75 \mathrm{kDa}$ and carbohydrate content of about $30 \%$ by weight. The optimum temperature of the CDA enzyme activity was determined in $M$. rouxii, $50 \mathrm{C}^{\circ}$ and the optimum $\mathrm{pH} 4.5$ [2].

According to the localization of CDA enzyme in fungi, it has been classified into two subgroups: extracellular CDA and intracellular CDA, extracellular chitin deacetylase (CDA) is secreted into the external medium while Intracellular CDA is secreted into the periplasm. Several fungi displaying both extracellular and intracellular CDA activity have been identified in recent years such as Aspergillus sp. [3].

Aspergillus flavus is a fungus that is widely dispersed in nature and mostly found at cereal grains and legumes such as corn, rice and peanuts. A. flavus grown in agricultural crops before harvest or through storage[4]. Fungus growth is affected by environmental conditions such as relative humidity and temperature [5]. The relative humidity of $85 \%$ or more is a favorable environment for the growth of A. flavus [6].

Several types of fungi were reported as CDA enzyme producer [7]. The first fungal CDA enzyme was extracted from the culture of the fungus $M$. rouxii [1]. In addition, an extracellular CDA was produced from two fungal isolates of Mortierella sp. [8], and Absidia corymbifera [9] isolated from soil. Furthermore, a novel CDA producing strain of Penicillium oxalicum was obtained from residual materials of seafood processing industries [10].

RSM-central composite design (CCD) was employed in the present investigation to optimize the significant parameters identified by the Plackett Burman design for further fine-tuning of CDA production. Statistical methodologies are useful tools to study the interaction between the physiological factors that play important roles in biotechnological processes [11].

Response surface methodology (RSM) is considered as an accurate, effective and simple approach for optimization of the experimental process [12] and has been successfully used in agriculture, biology, food, chemistry and other fields [13].

In this work, both classical and statistical methods were used to to optimize the fermentation parameters in order to maximize the production of CDA in solid-state fermentation from A.flavus.

\section{Materials and methods}

Microorganism

CDA-producing fungus of Aspergillus sp. was selected from 172 soil isolates of different molds based on its ability to produce higher amount of the enzyme in comparison with other isolates. The 
selection was achieved via a screening program involved two steps: primary screening on chitinase detection medium (contains per liter of distill water: colloidal chitin $1 \mathrm{~g}, \mathrm{KH}_{2} \mathrm{PO}_{4} 0.7 \mathrm{~g}, \mathrm{~K}_{2} \mathrm{HPO}_{4} 0.3 \mathrm{~g}$, $4 \mathrm{NaCl} 4 \mathrm{~g}, \mathrm{MgSO}_{4} \cdot 7 \mathrm{H}_{2} \mathrm{O} 0.5 \mathrm{~g}$ and was solidified with $2 \%$ agar) and CDA detection solid medium (contain per liter of distilled water: chitin $1 \mathrm{~g}$, sodium nitrate $2 \mathrm{~g}, \mathrm{~K}_{2} \mathrm{HPO}_{4} 1 \mathrm{~g}, \mathrm{KH}_{2} \mathrm{PO}_{4} 1 \mathrm{~g}$, 4nitroacetanilid $0.5 \mathrm{~g}, \mathrm{MgSO}_{4} .7 \mathrm{H}_{2} \mathrm{O} 0.5 \mathrm{~g}$, yeast extract $0.5 \mathrm{~g}$ and agar-agar $20 \mathrm{~g}$ ) $\mathrm{pH}$ was adjusted to 7 [14]. Secondary screening was achieved in SSF using rice bran supplemented with $2 \%$ of chitin.

Spores suspension of fungal isolates were prepared by adding $5 \mathrm{ml}$ of sterilized distilled water to the fungal culture vial on potato dextrose agar (PDA). The surface of agar culture was gently streaked using loop. Then spore suspension was transferred to sterilized container and counted by hemocytometer to be approximately $\left(1 \times 10^{6}\right.$ spore $\left./ \mathrm{ml}\right)$.

\section{Cultivation conditions}

The CDA-producing isolate was cultivated on the solid substrates as follow: Erlenmeyer flasks $(100 \mathrm{ml})$ contained $10 \mathrm{~g}$ of solid substrate was moisturized with sodium phosphate buffer $(0.05 \mathrm{M})$ with ratio $(1: 1)(\mathrm{W} / \mathrm{V})$. After sterilization at $121 \mathrm{C}^{\circ}$ for $20 \mathrm{~min}$, each flask was inoculated with $2 \mathrm{ml}$ of spore suspension from the selected isolate contained approximately $\left(1 \times 10^{6} / \mathrm{ml}\right)$. The flasks were then incubated aerobically at $30 \mathrm{C}^{\circ}$ in an incubator for 6 days [15]. After incubation, crude enzyme was extracted by adding $40 \mathrm{ml}$ of distilled water and then mixed well by using spatula and shaking for at least 2 hours. Next, cotton gauze was used to separate the solid materials and the supernatant was collected which was used as crude enzyme solution. Next, the collected filtrate was centrifuged in a cooling centrifuge with $10000 \mathrm{rpm}$ for $30 \mathrm{~min}$ at $4 \mathrm{C}^{\circ}$. Enzyme activity $(\mathrm{U} / \mathrm{ml})$ and enzyme production (U/g media) were measured [16, 17].

\section{Identification of Aspergillus flavus isolate}

Molecular identification by nucleotide sequence of the 16S rRNA through using primers specifically designed was performed for the local isolate Aspergillus. The 16s rRNA sequence alignment was compared to other prokaryotic $16 \mathrm{~S}$ rDNA sequences by using the similarity rank analysis service of NCBI database by BLAST server. Specific PCR primer was used in this experiment as shown in Table-1.

Table 1- PCR primers used in the identification of Aspergillus flavus

\begin{tabular}{|c|c|c|c|}
\hline Primer name & Sequence & Tm & Size \\
\hline ITS1 Forward & TCCGTAGGTGAACCTGCGG & \multirow{2}{*}{55} & $500 \mathrm{bp}$ \\
\hline ITS4 Reverse & TCCTCCGCTTATTGATATGC & & \\
\hline
\end{tabular}

\section{Optimization experiments}

The optimum conditions for CDA enzyme production by the selected isolate was investigated by two optimization strategies: classical optimization based on the method of one factor at a time and statistical optimization using response surface methodology. These experiments included type and concentration of moisture solution, incubation time, $\mathrm{pH}$ and inoculum size. Some physical parameters that were not investigated in this study have been adjusted according to the literature such as temperature

\section{Classical optimization of Chitin Deacetylase (CDA) Selection of substrate}

Substrates of rice, corn, rice bran and wheat bran (separately or supplemented with $2 \%$ chitin) were tested for supporting the production of CDA enzyme. Erlenmeyer flasks $(100 \mathrm{ml})$ each contained $10 \mathrm{~g}$ of the solid substrate was moisturized with sodium phosphate buffer $(0.05 \mathrm{M})$ adjusted to $\mathrm{pH}=7$, at ratio of $(1: 1)(\mathrm{W} / \mathrm{V})$. The flasks were then sterilized, inoculated with $2 \mathrm{ml}$ of spore suspension from the selected isolate contained approximately $\left(1 \times 10^{6} / \mathrm{ml}\right)$ and incubated under the same conditions, aerobically at $30 \mathrm{C}^{\circ}$ in an incubator for 6 days.

After incubation, crude enzyme was extracted by adding $40 \mathrm{ml}$ of distilled water to each flask. The mixture in each flask was mixed well by using spatula and all flasks were then put in a shaker for at least 2 hours. Next, cotton gauze was used to separate the solid materials and the supernatant was collected which was used as a crude enzyme solution. Next, the collected filtrate was centrifuged in a cooling centrifuge with $10000 \mathrm{rpm}$ for $30 \mathrm{~min}$ at $4 \mathrm{C}^{\circ}$. Enzyme activity $(\mathrm{U} / \mathrm{ml})$ and enzyme production (U/g media) were measured in the crude extract. 


\section{Types of moisture solutions}

Four different moisture types: the mineral salt solution (prepared by dissolving $2 \mathrm{~g} \mathrm{~K}_{2} \mathrm{HPO}_{4}$ and $1 \mathrm{~g}$ $\mathrm{MgSO}_{4} .7 \mathrm{H}_{2} \mathrm{O}$ in liter adjusted $\mathrm{pH}$ to 7 with sodium phosphate buffer $0.05 \mathrm{M}$ ) [15]; distilled water; tap water and $1 \%$ chitosan solution. These solutions were tested for their susceptibility to support the production of CDA enzyme. Erlenmeyer flasks $(100 \mathrm{ml})$ each contained $10 \mathrm{~g}$ of the selected solid substrate was moisturized with the four different moisture solutions separately with ratio (1:1) (W/V). The flasks were then sterilized, inoculated and incubated under the same conditions described in the previous of cultivation conditions.

\section{Optimum incubation times}

The production of CDA enzyme was investigated in six days of incubation in order to determine the optimum time that can be used to harvest the enzyme from the fermentation medium. Erlenmeyer flasks

$(100 \mathrm{ml})$ each contained $10 \mathrm{~g}$ of the selected solid substrate was moisturized with the selected moisture solution at ratio (1:1) (W/V). The flasks were then sterilized, inoculated under the same conditions described in the previous section. Enzyme activity $(\mathrm{U} / \mathrm{ml})$ and enzyme production (U/g media) were measured every 24 hours for six days of incubation.

\section{Statistical optimization}

After the classical optimization step, response surface methodology based on central composite design was applied to optimize fermentation parameters ( $\mathrm{pH}$, moisture level and inoculum size) in order to increase the production of CDA. These parameters were chosen to generate CCD matrix with $\mathrm{pH}$ level from 6 to 8, moisture level from 1 to $3 \mathrm{ml}$ : $\mathrm{g}$ and inoculum size from 1 to $3 \%$ as explained in Table-1. The matrix was designed with 34 runs (each run represented one flask) included six replications of the centre point, two replications of factorial points and two replications of axial points Table-2. In all runs, flasks were then sterilized, inoculated under the same conditions described in the previous section. At the end of incubation, CDA activity was measured and obtained data were analysed by using design expert 7 .

Table 2- Upper and lower limit of each optimizing factors

\begin{tabular}{|c|c|c|c|c|c|c|}
\hline Factors & Units & $-\alpha$ & -1 & 0 & +1 & $+\alpha$ \\
\hline A: $\mathrm{pH}$ & & 5.32 & 6 & 7 & 8 & 8.68 \\
\hline B: Moisture level & $\mathrm{ml} / \mathrm{g}$ & 0.65 & 1 & 1.5 & 2 & 2.34 \\
\hline C: Inoculum size & $\mathrm{ml} / 10 \mathrm{~g}$ & 0.31 & 1 & 2 & 3 & 3.68 \\
\hline
\end{tabular}

Where: $+\alpha$ : upper axial point; $-\alpha$ : lower axial point; +1 : upper factorial point; -1 : lower factorial point 0 : centre point

\section{Data analysis}

Design expert 7 was used for design of experiment matrix and regression data analysis. The model was statistically analyzed to evaluate the analysis of variance (ANOVA). Determination coefficient $\mathrm{R}^{2}$ was used to express the quality of the fit of the polynomial model equation, F-test was used to identify the significant of statistical analysis and significance of the regression coefficient was determined by $t-$ test [18].

\section{Analytical method \\ CDA activity assay}

It was determined using 4-nitroacetanilid as a substrate. The reaction mixture $(1 \mathrm{ml})$ contained 0.2 $\mathrm{ml}$ of substrate 4-nitroacetanilide $(200 \mathrm{mg} / \mathrm{L}), 0.6 \mathrm{ml}$ of sodium phosphate buffer $\mathrm{pH} 7(0.2 \mathrm{M})$ and 0.2 $\mathrm{ml}$ of crude enzyme. The mixture was incubated at $50^{\circ} \mathrm{C}$ for $15 \mathrm{~min}$, and then the enzyme was inactivated by heating for $5 \mathrm{~min}$ in a boiling water bath.Deionized distilled water was added up to $2 \mathrm{ml}$ $(1 \mathrm{ml} /$ tube), the solution was centrifuged $(10000 \mathrm{rpm})$ for $15 \mathrm{~min}$. Blank tube contained (inactivation crude enzyme, buffer and substrate with same conditions of reaction). CDA activity was determined by measuring the amount of 4-nitroaniline released from 4-nitroacetanilide at OD 400nm based on the standard curve of 4-nitroaniline. One unit of CDA is defined as the activity that catalyzed the release of $1 \mu \mathrm{g}$ of 4-nitroanilin from 4-nitroacetanilid per hour under standard assay conditions [16].

\section{Determination of protein concentration}

Protein concentration was estimated according to Bradford [19]. 


\section{Determination degree of deacetylation (DDA)}

DDA of chitosan was determined by dissolving $10 \mathrm{mg}$ of chitosan in $10 \mathrm{ml}(0.01 \mathrm{M}) \mathrm{HCl}$-solution in a100 ml volumetric flask. After the chitosan was dissolved completely, the solution was diluted to 100 $\mathrm{ml}$ using de-ionized water. According to the standard curve, the concentration of $\mathrm{N}$-acetyl glucosamine was determined by measuring the solution absorbance at $199 \mathrm{~nm}$. Blank tube contained only of HCL-solution $(0.01 \mathrm{M})$. The relationship between the absorbency and the concentration of $\mathrm{N}$ acetyl glucosamine to determine the DDA assay is determined according to the following equation [20]:

$$
\text { DDA }=100 \%-\mathrm{C} 1 / \mathrm{C}
$$

Where: $\mathrm{C} 1=$ Acetyl concentration of sample $(\mathrm{OD} 199 \mathrm{~nm}) ; \quad \mathrm{C}=$ Concentration of sample $(0.1 \mathrm{mg} / \mathrm{ml})$ Purification of Chitin Deacetylase (CDA)

CDA enzyme was partially purified by gel filtration chromatography using Sephacryl S-200column. First, the volume of crude enzyme solution was concentrated to $10 \mathrm{ml}$ by sucrose using dialysis tubes, (10 KDa MW cutoff) [21]. The concentrated enzyme $(10 \mathrm{ml})$ was passed through Sephacryl S-200 Column, and the elution step was done by $0.05 \mathrm{M}$ Tris- $\mathrm{HCl}$ buffer solution, $\mathrm{pH} 5.8$ with a flow rate of $20 \mathrm{ml} / \mathrm{hr}$ and $3 \mathrm{ml}$ for each fraction. The protein concentration was estimated in each fraction at wavelength $280 \mathrm{~nm}$. Thereafter, the enzyme activity $(\mathrm{U} / \mathrm{ml})$ was measured in fractions showed absorbance at $280 \mathrm{~nm}$.

\section{Characterization of CDA \\ Effect of pH on CDA activity}

The effect of $\mathrm{pH}$ on CDA activity was determined in $0.1 \mathrm{M}$ sodium acetate buffer $\mathrm{pH} 4,4.5,5,5.5$ and 6; 0.1M sodium phosphate buffer $\mathrm{pH} \mathrm{7,7.5} \mathrm{and} \mathrm{8;} \mathrm{0.1M} \mathrm{Tris-base} \mathrm{buffer} \mathrm{pH} \mathrm{9,9.5} \mathrm{and} \mathrm{10.} \mathrm{In}$ order to determine the effect of $\mathrm{pH}$ on CDA enzyme activity. $0.2 \mathrm{ml}$ of 4-nitroacetanilid solution was mixed with buffers to achieve the desired $\mathrm{pH}$ values between 4 and 10 . The enzyme activity was measured in each $\mathrm{pH}$ adjusted enzyme solution as mentioned in section and the relation between enzyme activities $(\mathrm{U} / \mathrm{ml})$ toward $\mathrm{pH}$ values was plotted to determine the optimum $\mathrm{pH}$ of CDA enzyme activity [17].

\section{Effect of pH on CDA stability}

Equal volume from partially purified enzyme was mixed with buffers at a ratio of (1:1) (v: v). The mixture was incubated in a water bath at $30 \mathrm{C}^{\circ}$ for 15-20 min. Enzyme activity was then determined and the relation between the percentage of remaining activity toward $\mathrm{pH}$ values was plotted [17].

\section{Effect of temperatures on CDA activity}

CDA activity was estimated in different temperatures $(30,40,50,55,60,65,70,75$ and 80$) \mathrm{C}^{\circ}$ and the relation between enzyme activities toward temperatures were plotted to determine the optimal temperature for enzymatic activity [17].

\section{Effect of Temperatures on CDA Stability}

CDA enzyme was incubated at different temperatures ranged between (30-80) $\mathrm{C}^{\circ}$ for $15-20 \mathrm{~min}$. Followed by incubation in ice bath. CDA enzyme activity was estimated and the relation between remaining activity percentage toward temperatures was plotted to determine the optimum temperatures of CAD enzyme stability [17].

\section{Results and discussion \\ Microorganism isolation and identification}

As mentioned earlier in this paper, CDA-producing mold of Aspergillus sp. was selected based on a screening program that involved two steps: first 77 isolates from 127 were selected based on their ability to grow and consume chitin, this was investigated by using chitinase detection medium [22]. Several studies have revealed that microorganisms, which have the ability to degrade chitin via producing chitinase, were presumed that would also produce CDA enzyme [23]. In addition, CDA detection solid medium, which contains 4-nitroacetanilide as an indicator. Results revealed that 41 isolates were grown in chitinase and created a yellow color on CDA detection medium. The diameter of yellow zone and the time of color appearance were significantly different which certainly, reflecting a variation in the ability of isolates for producing CDA. However, eight molds were grown with high diameter $(>40 \mathrm{~mm})$ or a full yellow color on CDA detection medium assuming that they have high capability to produce CDA enzyme, and therefore they were selected for the next secondary screening. In the secondary screening, the ability of isolates to produce CDA was examined in SSF using rice bran supplemented with $2 \%$ of chitin as a solid substrate. Based on the results, the fungal isolate 
Aspergillus sp. F1 gave the highest productivity of CDA enzyme with $212.9 \mathrm{U} / \mathrm{g}$ solid substrate. The Aspergillus sp. F1 isolate was identified by molecular identification method. The PCR amplification product for the 16S rRNA based primers gave a sharp band on agarose gel electrophoresis in line (1) corresponding to approximately $600 \mathrm{bp}$ between $(500-1000 \mathrm{pb})$ in length compared to the universal DNA molecular ladder as shown in Figure-1. Sequencing of DNA for the PCR product was commercially performed by Chromas -Pro. Co. Australia as demonstrated below. The sequence was then compared with NCBI database by BLAST server and results reveal that this DNA belongs to A.flavus with $100 \%$ similarities to strain CMXY30197 with Gen Bank accession number of MG991671.1

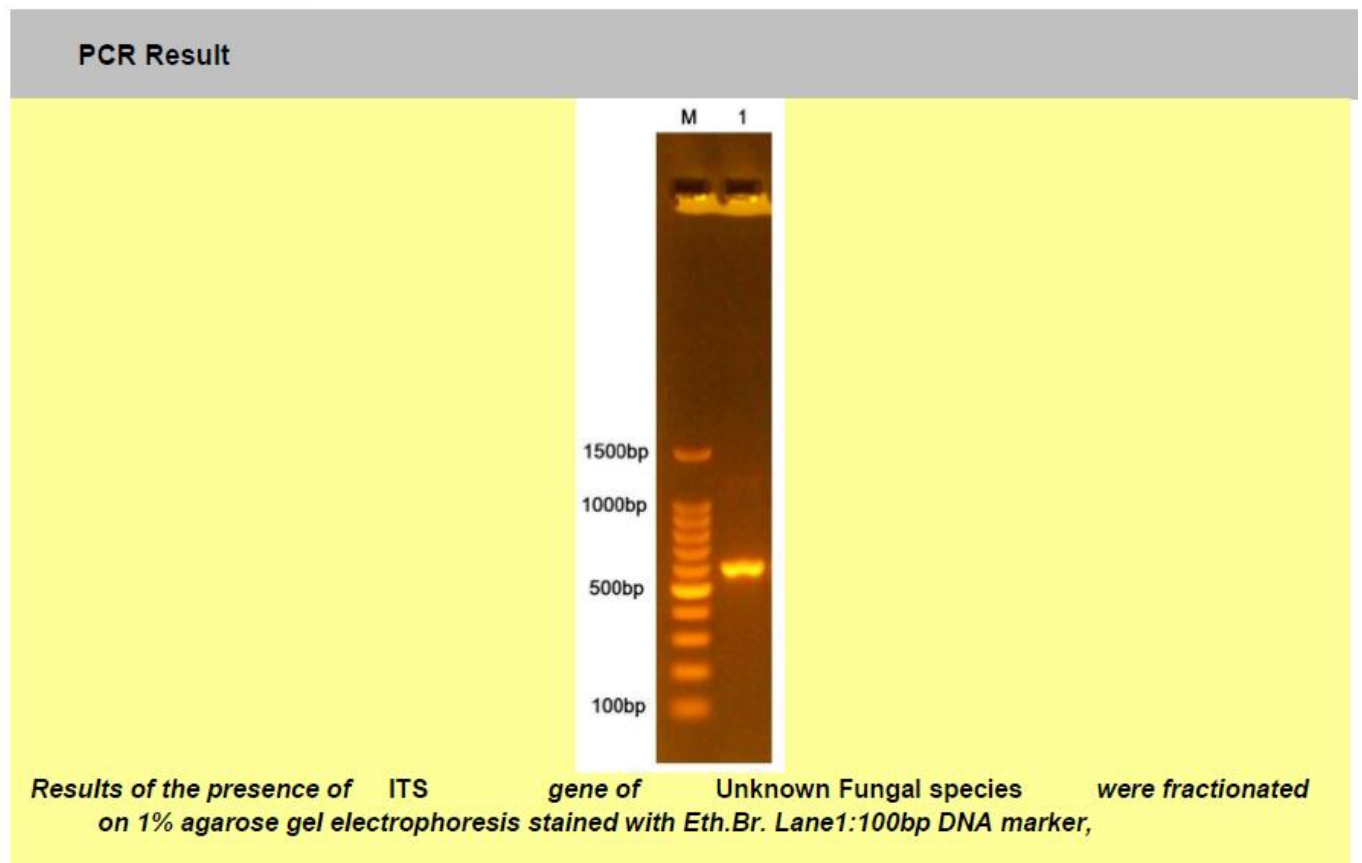

Figure 1- Fractionation on 1\% agarose gel electrophoresis stained with Eth.Br.

Lane M: 100bp DNA marker, Lane1: PCR product of ITS region.

\begin{abstract}
>Sample1 Forward
GGAAGGATCATTACCGAGTGTAGGGTTCCTAGCGAGCCCAACCTCCCACCCGTGTTTACTGTACCTTAGTTGCTTCGGCGGG CCCGCCATTCATGGCCGCCGGGGGCTCTCAGCCCCGGGCCCGCGCCCGCCGGAGACACCACGAACTCTGTCTGATCTAGTG AAGTCTGAGTTGATTGTATCGCAATCAGTTAAAACTTTCAACAATGGATCTCTTGGTTCCGGCATCGATGAAGAACGCAGCG AAATGCGATAACTAGTGTGAATTGCAGAATTCCGTGAATCATCGAGTCTTTGAACGCACATTGCGCCCCCTGGTATTCCGGG GGGCATGCCTGTCCGAGCGTCATTGCTGCCCATCAAGCACGGCTTGTGTGTTGGGTCGTCGTCCCCTCTCCGGGGGGGACG GGCCCCAAAGGCAGCGGCGGCACCGCGTCCGATCCTCGAGCGTATGGGGCTTTGTCACCCGCTCTGTAGGCCCGGCCGGC GCTTGCCGAACGCAAATCAATCTTTTCCAGGTTGACCTCGGATCAGGTAGGGATACCCGCTGAACTTAAGC
\end{abstract}

\begin{abstract}
>Sample1 Reverse
GCTTAAGTTCAGCGGGTATCCCTACCTGATCCGAGGTCAACCTGGAAAAGATTGATTTGCGTTCGGCAAGCGCCGGCCGGG CCTACAGAGCGGGTGACAAAGCCCCATACGCTCGAGGATCGGACGCGGTGCCGCCGCTGCCTTTGGGGCCCGTCCCCCCCG GAGAGGGGACGACGACCCAACACACAAGCCGTGCTTGATGGGCAGCAATGACGCTCGGACAGGCATGCCCCCCGGAATAC CAGGGGGCGCAATGTGCGTTCAAAGACTCGATGATTCACGGAATTCTGCAATTCACACTAGTTATCGCATTTCGCTGCGTTC TTCATCGATGCCGGAACCAAGAGATCCATTGTTGAAAGTTTTAACTGATTGCGATACAATCAACTCAGACTTCACTAGATCA GACAGAGTTCGTGGTGTCTCCGGCGGGCGCGGGCCCGGGGCTGAGAGCCCCCGGCGGCCATGAATGGCGGGCCCGCCGA AGCAACTAAGGTACAGTAAACACGGGTGGGAGGTTGGGCTCGCTAGGAACCCTACACTCGGTAATGATCCTTCC
\end{abstract}

\title{
Classical optimization of CDA \\ Selection of substrate
}

Based on the results presented in (Fig.1), the highest production of CDA enzyme was observed when A. flavus F1 was grown in corn supplemented with $2 \%$ chitin with an enzyme activity of 219.5 $\mathrm{U} / \mathrm{g}$ media and $(69.7 \mathrm{U} / \mathrm{ml})$. Production of extracellular CDA has gained much more interest in recent 
years, owing to its potential in the preparation of chitosan in industry. Suresh et al., [24] used wheat bran and shrimp processing by-product as solid substrates for the production of extracellular chitin deacetylase by SSF using two native soil fungal strains. On the other hand, several studies reported that chitinase and chitin deacetylase are inductive enzymes, and therefore in order to increase their production, chitin or its derivatives have to be added to the medium. In this work, when chitin powder was added to the solid media, enzymes production was induced.

\section{Types of moisture solution}

As can be seen from the results presented in Figure-2, A. flavus F1 gave the highest productivity when the solid medium was moisturized with mineral salt solution. The production of CDA enzyme in this medium was $210 \mathrm{U} / \mathrm{g}$ media and $(66.67 \mathrm{U} / \mathrm{ml})$ for enzyme activity. In this work, chitosan solution was used for moisturizing corn substrate according to the fact that chitosan can induce the production of CDA. In this context, wheat bran medium was supplemented with $1 \%$ (w/w) commercial chitosan powder as an inducer [24]. Loung et al., [15] used salt solution to moisturize 20g of different types of SSF (rice bran, rice, corn with and without chitin) at 1:1(w/v) level to produce CDA enzyme from Streptomyces sp. After incubation at $30 \mathrm{C}^{\circ}$ for 4 days, a high productivity of CDA enzyme $(170 \mathrm{U} / \mathrm{g}$ media) was obtained in a rice bran medium supplemented with chitin.
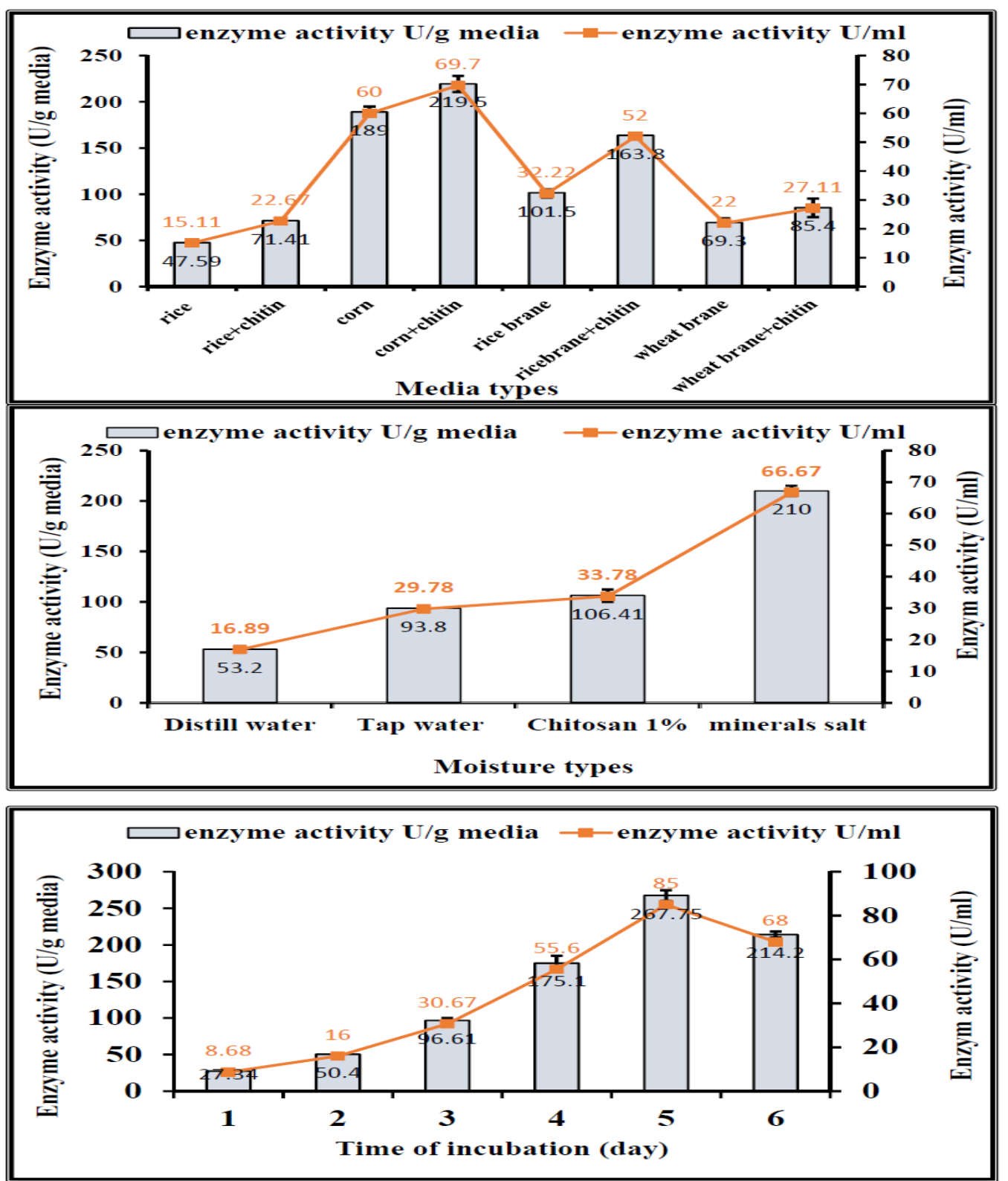

Figure 2- Classical optimization of solid substrate, moisture types and incubation time for CDA production from A. flavus $\mathrm{F} 1$ in solid-state fermentation 


\section{Optimum incubation times}

In Figure-1 shows, that maximum production of CDA enzyme in corn substrate supplemented with chitin was achieved at the fifth day of incubation in which the production of enzyme reached to 267.75 $\mathrm{U} / \mathrm{g}$ media with $85 \mathrm{U} / \mathrm{ml}$. Chitin deacetylase are usually secreted during an exclusive period corresponding to their special biological roles. CDA enzyme from fungal species might be secreted during different periods of incubation based on the cultivation condition and the type of fungal strain. According to the results, CDA enzyme was decreased in sixty days of incubation which may be either due to the depletion of nutrients in the fermentation medium or production of inhibitory products that may cause inactivation of secretary machinery of the enzymes as CDA enzyme plays a significant role only during the growth phase of the fungus [25]. For instance, an extracellular CDA from Colletrichum lindemuthianum was exclusively secreted during fungal hyphae penetration in to plants to modify chitin that could be recognized as plant resistance system. In contrast, an intracellular CDA from Mucor rouxii was produced during fungal cell wall formation [26]. In shrimp processing byproduct medium (SPP), Penicellium monoverticillium produced higher CDA activity of $390.2 \mathrm{U} / \mathrm{g}$ media after $96 \mathrm{~h}$ of incubation compared with the maximum production of $220.1 \mathrm{U} / \mathrm{g}$ media at $120 \mathrm{~h}$ of incubation produced by Fusarium oxysporum [27].

\section{Statistical optimization of CDA}

Optimization of a medium by the classical method involves changing one independent variable at a time while keeping others at a fixed level. This is extremely time consuming and expensive for many variables. In contrast, the optimization process based on statistical method helps to minimize the number of experiments. In addition, it assists to construct an approximation model that used to study the interaction between numbers of fermentation variables. Adinarayana et al., 2003) [28]. As mentioned earlier, statistical optimization was set with three factors: $\mathrm{pH}$, inoculation size and moisture level to obtain the highest response (enzyme activity U/g media). The matrix was designed with 34 runs presented in Table- 3 with actual and predicted values of chitin deacetylase (U/g media) for each run.

Based on response values and data analysis for response (Chitin deacetylase CDA), and from fit summary analysis, quadratic model is the most suggested model for CDA production according to lake of fit test with P-value 0.169. Analysis of variance, ANOVA, for quadratic model was shown in Table-4, which performed to check adequacy and significance of model. Model fitness was evaluated using determination coefficient $\left(\mathrm{R}^{2}\right)$ which is in this case for CDA model was $\left(\mathrm{R}^{2}=0.9091\right)$ indicating that $9.09 \%$ of total variation was not explained by the model. Adequate precision for CDA was 17.38; this value used for measuring signal to noise which believed to be desirable greater than 4 . The adjusted and predicted determination coefficient for CDA was 0.875 and 0.8014 respectively, which are accepted values as the difference between them was less than 0.2. Based on ANOVA table for $\mathrm{CDA}$ production, all of the terms showed significant effect for CDA production except $\mathrm{AB}$ and $\mathrm{CC}$, which are not significant. Since most of the P-value, data showed 0.0001 in the ANOVA table. Therefore, the highest significant factors can be determined through F-value. Moreover, B-moisture level showed the most significant factor affecting on CDA production with F- value of 71.56 followed by BC with F- value 70.04 .

Response surfce methodology was applied to generate regression equation which is imperical relationship between tested variables and response [29]. After analysis of variance and estimation of regression coefficient, the experimental design was fitted in second order polynomeal equation (1) with coded factors A: $\mathrm{pH}, \mathrm{B}$ : moisture level, C: inoculum size.

$$
\begin{aligned}
& \mathrm{CDA}=+137.69+22.68(\mathrm{~A})-48.01(\mathrm{~B})+20.79(\mathrm{C})+3.19(\mathrm{AB})-19.06(\mathrm{AC})-62.06(\mathrm{BC})+37.31 \\
& \left(\mathrm{~A}^{\wedge 2}\right)-18.64\left(\mathrm{~B}^{\wedge 2}\right)-3.70\left(\mathrm{C}^{\wedge 2}\right)
\end{aligned}
$$


Table 3-Experimental design and results of central composite design for Chitinase deacetylase (CDA) production with actual and predicted value of response

\begin{tabular}{|c|c|c|c|c|c|c|c|}
\hline \multirow[b]{2}{*}{ std } & \multirow[b]{2}{*}{ run } & \multirow[b]{2}{*}{ point type } & \multicolumn{3}{|c|}{ Factors } & \multicolumn{2}{|c|}{$\begin{array}{c}\text { Chitin deacetylase } \\
\text { (U/g media) }\end{array}$} \\
\hline & & & pH & $\begin{array}{l}\text { moisture level } \\
(w: v)\end{array}$ & $\begin{array}{l}\text { inoculum size } \\
(\mathrm{ml} / \mathbf{1 0 g})\end{array}$ & Actual & Predict \\
\hline 10 & 1 & Fact & 6 & 1 & 3 & 280 & 283.08 \\
\hline 20 & 2 & Axial & 8.68 & 1.5 & 2 & 275 & 281.3 \\
\hline 24 & 3 & Axial & 7 & 2.34 & 2 & 40 & 4.2 \\
\hline 17 & 4 & Axial & 5.32 & 1.5 & 2 & 226 & 205.07 \\
\hline 12 & 5 & Fact & 8 & 1 & 3 & 312 & 283.9 \\
\hline 29 & 6 & Center & 7 & 1.5 & 2 & 138 & 137.6 \\
\hline 32 & 7 & Center & 7 & 1.5 & 2 & 139 & 137.6 \\
\hline 5 & 8 & Fact & 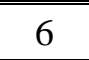 & 2 & $\overline{1} 1$ & 45 & 100.98 \\
\hline 9 & 9 & Fact & $\overline{66}$ & 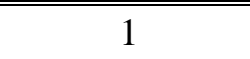 & 3 & 275 & 283.08 \\
\hline 14 & 10 & Fact & 6 & 2 & 3 & 66 & 56.5 \\
\hline 33 & 11 & Center & 7 & 1.5 & 2 & 138 & 137.6 \\
\hline 7 & 12 & Fact & 8 & 2 & 1 & 195 & 190.83 \\
\hline 18 & 13 & Axial & 5.32 & 1.5 & 2 & 220 & 205.07 \\
\hline 27 & 14 & Axial & 7 & 1.5 & 3.68 & 140 & 162.1 \\
\hline 15 & 15 & Fact & 8 & 2 & 3 & 45 & 70.2 \\
\hline 21 & 16 & Axial & 7 & 0.66 & 2 & 133 & 165.7 \\
\hline 26 & 17 & Axial & 7 & 1.5 & 0.32 & 110 & 92.2 \\
\hline 25 & 18 & Axial & 7 & 1.5 & 0.32 & 130 & 92.2 \\
\hline 23 & 19 & Axial & 7 & 2.34 & 2 & 45 & 4.2 \\
\hline 6 & 20 & Fact & 6 & 2 & 1 & 50 & 100.98 \\
\hline 2 & 21 & Fact & 6 & 1 & 1 & 93.1 & 79.2 \\
\hline 4 & 22 & Fact & 8 & 1 & 1 & 145 & 156.3 \\
\hline 8 & 23 & Fact & 8 & 2 & 1 & 185 & 190.83 \\
\hline 28 & 24 & Axial & 7 & 1.5 & 3.68 & 147 & 162.1 \\
\hline 22 & 25 & Axial & 7 & 0.66 & 2 & 140 & 165.7 \\
\hline 30 & 26 & Center & 7 & 1.5 & 2 & 133 & 137.6 \\
\hline 3 & 27 & Fact & 8 & 1 & 1 & 140 & 156.3 \\
\hline 1 & 28 & Fact & 6 & 1 & 1 & 98 & 79.2 \\
\hline 16 & 29 & Fact & 8 & 2 & 3 & 50 & 70.2 \\
\hline 11 & 30 & Fact & 8 & 1 & 3 & 350 & 283.5 \\
\hline 19 & 31 & Axial & 8.68 & 1.5 & 2 & 270 & 281.3 \\
\hline 13 & 32 & Fact & 6 & 2 & 3 & 62 & 56.5 \\
\hline 34 & 33 & Center & 7 & 1.5 & 2 & 140 & 137.6 \\
\hline 31 & 34 & Center & 7 & $\begin{array}{l}1.5 \\
\end{array}$ & 2 & 135 & $\begin{array}{l}137.6 \\
\end{array}$ \\
\hline
\end{tabular}


Table 4- The ANOVA analysis of quadratic model for CDA production by Aspergillus flavus Flin SSF based on CCD

\begin{tabular}{|c|c||c|c|c|c||}
\hline Sources & $\begin{array}{c}\text { Sum of } \\
\text { squares }\end{array}$ & $\begin{array}{c}\text { Degree of } \\
\text { freedom }\end{array}$ & $\begin{array}{c}\text { Mean } \\
\text { Square }\end{array}$ & F- value & $\begin{array}{c}\text { p-value } \\
\text { Prob > F }\end{array}$ \\
\hline \hline Model & 211167 & 9 & 23463 & 26.67164 & $<0.0001$ \\
\hline A-pH & 14046.18 & 1 & 14046.18 & 15.96704 & 0.0005 \\
\hline \hline B-Moisture level & 62951.81 & 1 & 62951.81 & 71.56068 & $<0.0001$ \\
\hline C-inoculum size & 11809.48 & 1 & 11809.48 & 13.42446 & 0.0012 \\
\hline \hline $\mathrm{AB}$ & 163.2006 & 1 & 163.2006 & 0.185519 & $0.6705^{*}$ \\
\hline $\mathrm{AC}$ & 5810.251 & 1 & 5810.251 & 6.604821 & 0.0168 \\
\hline $\mathrm{BC}$ & 61615.65 & 1 & 61615.65 & 70.04179 & $<0.0001$ \\
\hline $\mathrm{A}^{\wedge 2}$ & 31385.12 & 1 & 31385.12 & 35.67713 & $<0.0001$ \\
\hline $\mathrm{B}^{\wedge 2}$ & 7834.18 & 1 & 7834.18 & 8.905529 & 0.0064 \\
\hline $\mathrm{C}^{\wedge 2}$ & 309.1197 & 1 & 309.1197 & 0.351393 & $0.5589^{*}$ \\
\hline Residual & 21112.76 & 24 & 879.6984 & & \\
\hline \hline Lack of Fit & 19943.92 & 5 & 3988.785 & 64.83951 & $0.19^{*}$ \\
\hline \hline Pure Error & 1168.838 & 19 & 61.51781 & & \\
\hline Cor Total & 232279.7 & 33 & & & \\
\hline
\end{tabular}

$\mathrm{R}$-sq=0.9091 adj R-sq $=0.87 \quad$ pred R-sq=0.80 adeq precession $=17.38$

* Not significant

In addition to correlation, regression analyses can be used to assess the best fit of a line using the equation $y=\mathrm{b} 0+\mathrm{b} 1 x$. The ideal line of best fit will have the sum of the squares of the distances from $x$ to the line of fit as small as possible. The diagnostic of normal residual demonstrated in Figure-3 indicated that residual behavior followed a normal distribution and was quadratic, which is the more important assumption for checking statistical modeling. From this figure, it can be noted that the values calculated using the predictive quadratic model were in good agreement with the experimental values with a satisfactory correlation between these values. Therefore, it can be said that the developed model is suitable for predicting CDA enzyme activity (U/g media) production under suggested composition.

Validation of optimum conditions for CDA enzyme production based on the enhanced regression model was obtained. Optimization plot in ramp chart was generated using the design expert 7 software in order to determine the optimum $\mathrm{pH}$, moisture level and inoculum size that elevated CDA production. Results showed that, the optimum $\mathrm{pH}$, moisture level and inoculum size were 8, 1:1 (10ml: $10 \mathrm{~g}$ ) and $(3 \mathrm{ml}: 10 \mathrm{~g})$ respectively in order to obtain a maximum predicted CDA enzyme production of $283.8 \mathrm{U} / \mathrm{g}$ medium.

In order to verify the optimization, result and determine accuracy of model, an experiment was conducted in duplicate with optimized $\mathrm{pH}$, moisture level and inoculum size suggested by design expert 7 for CDA production. The result revealed that actual response of CDA was $312 \mathrm{U} / \mathrm{g}$ medium, which approximately closed to predict value $283.89 \mathrm{U} / \mathrm{g}$ medium. 

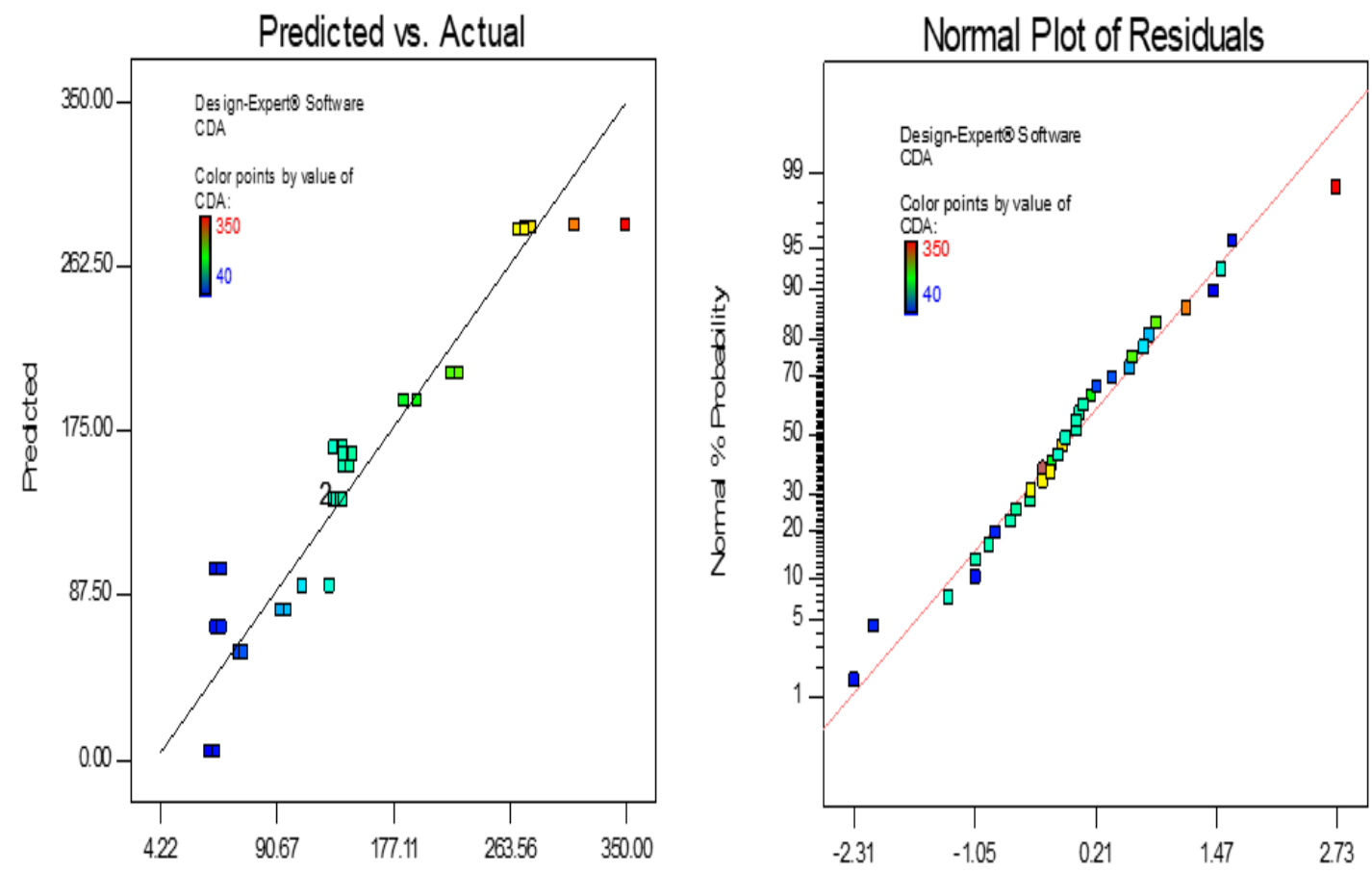

Intemally Studentized Residuals

Figure 3- Normal probability plot of standardized residuals of quadratic model based on CCD and actual versus predicted values for CDA production by A. flavus F1 in SSF

Statistical optimization methods allow studying the interactive effect of variables on the response and are hence highly effective in determining the optimal conditions. Similar identification of important process variables by the Placket -Burgman design experiments and the optimization of their levels by the RSM- central composite design (CCD) helped to achieve a CDA yield of $142 \mathrm{U} / \mathrm{g}$ media as compared to the unoptimized basal yield of $79 \mathrm{U} / \mathrm{g}$ media using wheat bran as the solid substrate [29]. Plackett-Burman design, steepest ascent design and RSM were used to investigate the interaction effects of independent variables important for the activity of CDA produced by Bacillus amyloliquefaciens and hence, the optimum medium composition for obtaining high CDA was confirm [30].

\section{Purification of CDA}

The crude extract of CD was concentrated by sucrose. The results showed that $61 \%$ of CDA enzyme was yielded with a purification fold of 1.1 Table-5, Sucrose was formerly widely used for the concentration of proteins, it almost used as an inexpensive way of precipitating and concentrating a protein extract [21]. Reported that the method for the concentration the enzyme by reducing the volume of the active solution by dialyzing against a concentrated solution of sucrose, through withdrawal of water molecules from the enzymatic solution. The solution of concentrated CDA enzyme obtained by sucrose step was passed through a Sephacryl S- 200 gel filtration column and results indicated the presence of peak with eleven fractions of protein however, CDA enzyme activity was found in fractions from 24 to 27 Figure-4. From the purification Table-5, the specific activity of CDA enzyme solution collected from the active tubes was $12300 \mathrm{U} / \mathrm{mg}$ proteins with purification fold 54.4 and yield of $62.1 \%$. 


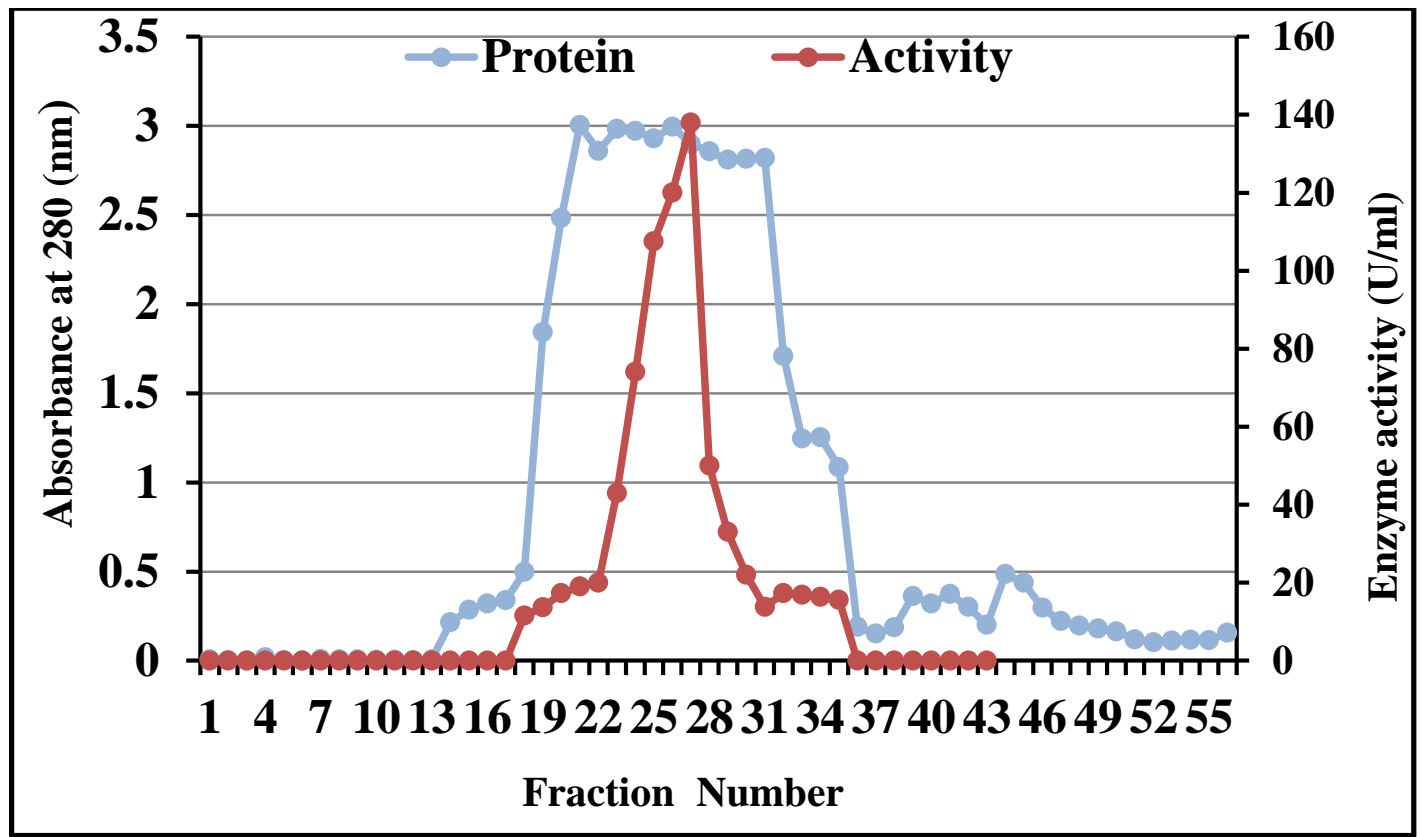

Figure 4- Gel-filtration chromatography for CDA purification from A. flavus F1 using Sephacryl S200 column $(22 \times 1.7) \mathrm{cm}$ equilibrated and eluted with Tris- $\mathrm{HCl}$ buffer $(0.05 \mathrm{M}, \mathrm{pH} 5.8)$, in flow rate $20 \mathrm{ml} / \mathrm{hr}$., $3 \mathrm{ml}$ for each fraction.

Table 5- The purification steps of CDA enzyme from A. flavus F1

\begin{tabular}{|c|c|c|c|c|c|c|c|}
\hline Purification steps & $\underset{>}{\stackrel{\Xi}{\Xi}} \widehat{\Xi}$ & 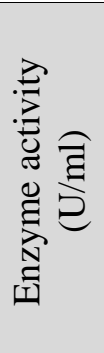 & 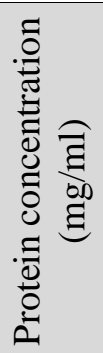 & 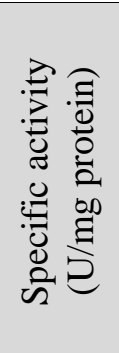 & 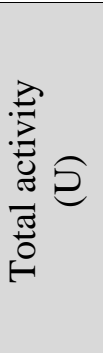 & 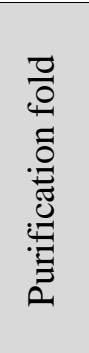 & 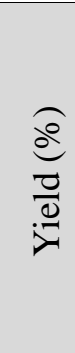 \\
\hline Crude extract & 30 & 79.2 & 0.35 & 226.3 & 2376 & 1 & 100 \\
\hline Concentration by sucrose & 10 & 144 & 0.6 & 240 & 1440 & 1.1 & 61 \\
\hline Gel filtration (Sephacryle S-200) & 12 & 123 & 0.01 & 12300 & 1476 & 54.4 & 62.1 \\
\hline
\end{tabular}

\section{Characterization of Chitin deacetylase (CDA)}

CDA enzyme has the maximum activity in $\mathrm{pH}$ ranged between (6-8), in which enzyme activity at pH 7 was 69 U/ ml Figure-5, Whereas, a reduction in enzyme activity was observed at acidic pH (45.5) and at alkaline $\mathrm{pH}(9-10)$, The optimum $\mathrm{pH}$ for the CDA in the present study was found to be the same as the optimum $\mathrm{pH}$ of CDA produced from Aspergillus nidulans strain. The CDA produced by a Colletotrichum lindemuthianum strain was found to be active in the alkaline $\mathrm{pH}$ range in 7 to 12 [31]. The CDA from a strain of A. flavus exhibited more than $50 \%$ of the highest activity between $\mathrm{pH} 4.0$ and 9.0, with maximum activity at $\mathrm{pH} 8.0$ and the stability of CDA enzyme was also exhibited in $\mathrm{pH}$ range of pH 3 and 10 (Karthika et al.,2017) [29].

In addition, Fig. 4 shows that the enzyme was retained $100 \%$ of its activity in $\mathrm{pH} 7.5$ while retained $97 \%$ of its activity in $\mathrm{pH} 8$ and about $95.8 \%$ and $93 \%$ at $\mathrm{pH} 7$ and 6 respectively. However, the activity was decreased when the $\mathrm{pH}$ was either above 8 or lower 7 ; the remaining activities were $90 \%$ at $\mathrm{pH} 5.5$ and $86.5 \%, 81.9 \%, 79 \%, 77.7 \%, 67 \%$ and $64.3 \%$ at $\mathrm{pH} 5,4.5,4,9,9.5$ and 10 , respectively. Therefore, it can be said that the enzyme stability has a wide range in acidic and alkaline $\mathrm{pH}$. In general, this lowering activity at $\mathrm{pH}$ values away from the optimum condition may due to the effect of $\mathrm{pH}$ in enzyme structure which lead to denature the enzyme molecular or to a change in the ionic state 
of the enzyme active site. In addition, its effect on secondary and tertiary structure of the enzyme leads to losing the activity in buffers solution that far away from optimal $\mathrm{pH}$. On the other hand, the results in Figure-4 indicated an increase in the activity until $50 \mathrm{C}^{\circ}$, in which CDA activity reached to $70 \mathrm{U} / \mathrm{ml}$. Then, the activity was declined with increasing temperature up to $55 \mathrm{C}^{\circ}$ with a minimum activity $(8$ $\mathrm{U} / \mathrm{ml}$ ) observed at $80 \mathrm{C}^{\circ}$. In the literature, the optimum temperature for most microbial CDAs is within $50-60 \mathrm{C}^{\circ}$ with a moderate activity within the range of $30 \mathrm{C}^{\circ}$ to $70 \mathrm{C}^{\circ}$. The thermal stability of CDA was reported and is generally observed up to $50 \mathrm{C}^{\circ}$. Moreover, it was found that the enzyme was maintained its activity at temperatures ranged between $(30-55) \mathrm{C}^{\circ}$, then the activity began to decrease with increasing temperature; the results showed that at $60 \mathrm{C}^{\circ}$ about $39.2 \%$ of the activity was remained Figure-4. Higher temperatures showed sharp decrease in the stability; the enzyme retained approximately $18.2 \%$ and $14.9 \%$ of its initial activity at $70 \mathrm{C}^{\circ}$ and $75 \mathrm{C}^{\circ}$ respectively, whereas, at $80 \mathrm{C}^{\circ}$ remaining CDA enzyme activity was $7.8 \%$. The decline in CDA enzyme activity at high temperature more than $65 \mathrm{C}^{\circ}$ may due to the damage in the $3 \mathrm{D}$ structure of the protein because of damaging Rgroups of amino acids leading to denature of protein and consequently losing its activity [32]. Karthika et al (2017) [29] reported that the optimum temperature of CDA enzyme isolated from A. flavus was $50 \mathrm{C}^{\circ}$; they found that the CDA stability was significantly reduced above this temperature.

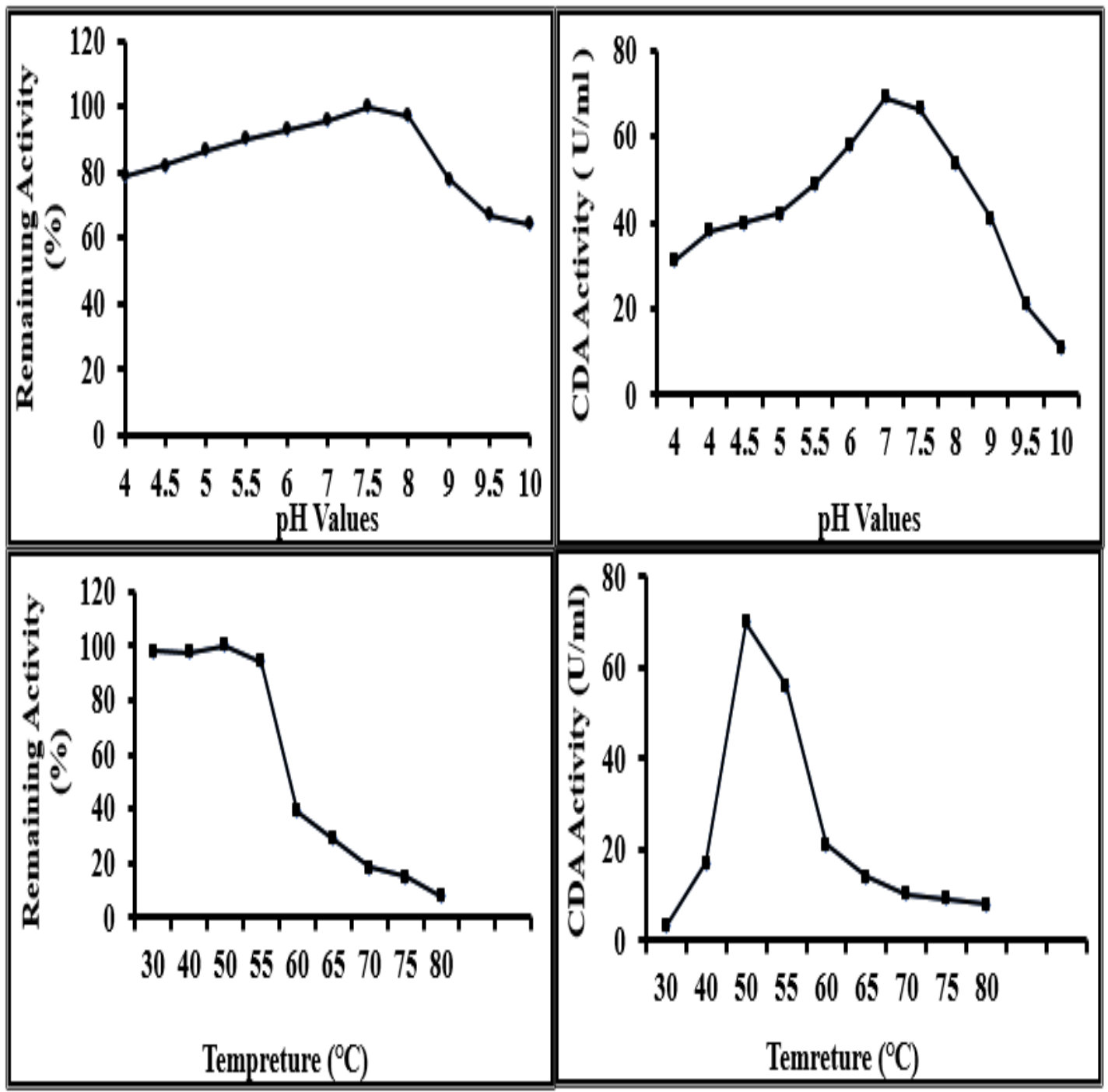

Figure 5- Effect of $\mathrm{pH}$ and temperature on the activity and stability of CDA enzyme produced by $A$. flavus $\mathrm{F} 1$ using 4-nitroacetanilid as substrate. 


\section{References}

1. Araki, Y. and Ito, E. 1975. A pathway of chitosan formation in Mucor rouxii: Enzymatic deacetylation of chitin. Eur. J. Biochem. 189: 249-253.

2. Kafetzopoulos, D., Martinou, A. and Bouriotis, V. 1993. Bioconversion of chitin to chitosan: Purification and characterization of chitin deacetylase from Mucor rouxii. Proc. Natl. Acad. Sci. USA. 90: 2564-2568.

3. Cai, J., Li, J., Wang, C., Lin, J., Hu, Y., Yang, J., Du, Y. and Zheng, H. 2013. Parametric optimization of extracellular chitin deacetylase production by Scopulariopsis brevicaulis. $J$ Biocatal Biotransfor, 2:1-5.

4. Saini, S. and Kaur, A. 2012. Aflatoxin B1: Toxicity, characteristics and analysis. Global Advanced Research Journal of Chemistry and Material Science, 1(4): 063-070.

5. Giorni, P., Leggrieri, M.C., Magan, N. and Battilani, P. 2012. Comparison of temperature and moisture requirements for sporulation of Aspergillus flavus sclerotic on natural and artificial substrates. Fungal Biol. 116: 637-642.

6. Al-Shikli, R.A., Abdulrasool, A.A. and Al-Hiti, M.M. 2010. Effect of some storage condition upon the survival of some fungal spores. Iraqi J Pharm Sci. 19(2): 1-10.

7. Yuanhao He, Jianping Xu, Shengjie Wang, Guoying Zhoua and Junang Liua. 2013. Optimization of medium components for production of chitin deacetylase by Bacillus amyloliquefaciens Z7, using response surface methodology. Biotechn \& Biotechnological Equipment, 28(2): 242-247.

8. Kim, Y., Yeo, S., Kim, M. K. and Choi, H. T. 2008. Removal of estrogenic activity from endocrine-disrupting chemicals by purified laccase of Phlebia tremellosa. FEMS J Microbiol Let. 284: $172-175$.

9. Zhao, Y., Kim, YJ., Oh, KT., Van Nguyen, N. and Park, RD. 2010. Production and characterization of extracellular chitin deacetylase from Absidia corymbifera DY-9. J Kor Soc Appl Biol Chem. 53:119-126.

10. Pareek, N., Vivekanand, V., Dwivedi, P. and Singh, RP. 2011. Penicillium oxalicum SAEM-51: a mutagenised strain for enhanced production of chitin deacetylase for bioconversion to chitosan. New Biotechnol, 28:118-124.

11. Seker, UOS., Catal, T., Taptik, Y., Tamerler, C. and Bermek, H. 2008. Enhanced production of manganese-peroxidase by the white rot fungus Bjerkandera adusta using media engineering. Biotechnol. 22(3): 844-848.

12. Hilde, HW. and Nigel, B. 2010. The optimization of solid-liquid extraction of antioxidants from apple pomace by response surface methodology. J Food Eng. 96: 134-140.

13. Wang, Y., Wang, T. and Ding, L. 2012. Optimization of polysaccharide extraction from Angelica sciences using response surface methodology. Food Sci. 33: 146-149.

14. Sonu Rani Kashyap and Neelam Garg. 2011. Isolation, Production, Quantitative assay and Optimization of Chitin deacetylase from Yeast. Schol Acad J Biosc. 2(1): 43-47.

15. Loung, D.T., Tuan, N.A., Van, N.T., Yen, L.T.H., Jasper-Versali, M.F., Dommes, J. and Hop. D.V. 2010. Study in an Actinomycetes producing chitinase and chitin deacetylase. International center for biotechnology Osaka University.439-449.

16. Yuying Sun., Jiquan Zhang., Shengjun Wu and ShujunWang. 2014. Statistical optimization for production of chitin deacetylase from Rhodococcus erythropolis HG05. J of Els. 102: 249-252.

17. Al-Assadi, S.I. 2017. Biodegradation of industrial dyes in a bioreactor by free and immobilized laccase from local isolate of Pseudomonas aeruginosa SR. Ph.D. thesis, Department of Biotechnology, College of Science, University of Baghdad, Iraq.

18. Montgomery, D.C. Design and Analysis of Experiments. 2011. John Wiley \& Sons, Inc.: Hoboken, NJ, USA. pp: 456.

19. Bradford, M. 1976. A rapid and sensitive method for the quantitation of microgram quantities of protein using the principle of protein-dye binding. Anal Bioch J. 72: 248-254.

20. Yuan, Y., Chesnutt, B.M., Haggard, W.O., Bumgardner, J.D. 2011. Deacetylation of chitosan: material characterization and in vitro evaluation via albumin adsorption and pre-osteoblastic cell cultures. Materials, 4: 1399-1416.

21. Bajaj, B. K. and Singh, N. P. 2010. Production of xylanase from an alkali tolerant Streptomyces sp. $7 \mathrm{~b}$ under solid-state fermentation, its purification, and characterization. J Appl Bioch Biotech. 162: 180-188. 
22. Kyoung-Ja Kim, Yong-Joon Yang † and Jong-Gi Kim. 2003. Purification and Characterization of Chitinase from Streptomyces sp. M-20. Journal of Biochemistry and Molecular Biology, 36(2): 185-189.

23. Alexander, M. 1985. "Introduction to Soil Microbiology". Wiley Eastern, $2^{\text {nd }}$ edition.

24. Suresh, PV., Sachindra, NM., and Bhaskar, N. 2011. Solid-state fermentation production of chitin deacetylase by Colletotrichum lindemuthianum ATCC 56676 using different substrates. J Food Sci Technol. 48: 349-356.

25. Karthik, N., Binod, P., Pandey, A. 2015. Production of chitin deacetylase by Aspergillus flavus in submerged conditions. Prep Biochem Biotechnol. 46: 501-508.

26. Davis, L. L., and Bartnicki-Garcia, S. 1984. Biochemistry. 23: 1065-1073.

27. Suresh, P. Z., Sakhare, N. M., Sachindra, P. M. and Halami. 2014. Extracellular chitin deacetylase production in solid-state fermentation by native soil isolates of Penicillium monoverticillium and Fusarium oxysporum. J Food Sci Technol. 51(8):1594-1599.

28. Adinarayana K., Prabhakar, T., Srinivasulu, V., Anitha, RM., Jhansi, LP. and Ellaiah, P. 2003 Optimization of process parameters for cephalosporin $\mathrm{C}$ production under solid state fermentation from Acremonium chrysogenum. Pro biochem. 39: 171-177.

29. Karthik, N., Binod, P. and Pandey, A. 2017. SSF production, purification and characterization of chitin deacetylase from Aspergillus flavus. Biocat biotransf. 36: 2018-4.

30. Yuanhao He, Jianping Xu, Shengjie Wang, Guoying Zhoua, and Junang Liu. 2014. Optimization of medium components for production of chitin deacetylase by Bacillus amyloliquefaciens Z7, using response surface methodology. Biotechnology \& Biotechnological Equipment. 28(2): 242247.

31. Tokuyasu, K., Ohnishi-Kameyama, M. and Hayashi, K. 1996. Purification and characterization of extracellular chitin deacetylase from Colletotrichum lindemuthianum. Biosci Biotechnol Biochem. 60: $598-1603$.

32. Chesworth, J.M., Stuchbury, T. and Scaif, J. R. 1998. An introduction to agricultural biochemistry. Chapman \& Hall, London. 5(2): 215-223. 